\title{
"Ett universum av tecken" Intertextuella relationer i femton svenska recensioner av Michel Houellebecqs Underkastelse
}

\author{
Erik Larsson
}

\section{Inledning}

Michel Houellebecqs roman Underkastelse gavs ut samma dag som den blodiga terroristattacken mot satirtidskriften Charlie Hebdo i Paris. Denna omständighet i kombination med det kontroversiella scenario romanen beskriver - ett muslimskt maktövertagande av Frankrike - ledde till att den fick enormt mycket uppmärksamhet i media. Ingrid Elam inleder sin recension av boken i Ystads Allehanda med att redogöra för dessa händelser för att sedan konstatera att det "mycket tidigt blev [...] för sent att läsa romanen i ett annat ljus än det mörker som lägrade sig över Paris”. ${ }^{1}$

I det följande är det emellertid inte romanen i sig som står i fokus, utan i stället de recensioner den givit upphov till i svenska dags- och kvällstidningar. Dessa ska studeras med avseende på de intertextuella relationer de rymmer.

\section{Bakgrund}

Termen kritik kan vara något besvärlig, inte minst eftersom den engelska motsvarigheten "criticism" har en delvis annorlunda betydelse. Tomas Forser reder i boken Kritik av Kritiken ut begreppen något: "När amerikaner och engelsmän skriver om 'criticism' avser de inte bara det vetenskapliga studiet av litteratur. De kan också syfta på dagskritik. När vi talar om kritik syftar vi inte bara på litteraturkritik som dagstidningsanmälningar. Vi kan också avse polemik, essäistik, historieskrivning och den emancipatoriska vetenskap som ibland kallas 'kritisk teori'” (Forser 2002: 9). I det följande avses med termen litteraturkritik dagstidningsrecensioner (eller dags- och kvällstidningsrecensioner, eftersom studien inkluderar två texter ur kvällspressen) och inget annat. Andra typer av litteraturkritiska texter, till exempel de man hittar i tidskrifter, finns alltså inte representerade i det studerade materialet.

Litteraturkritiken som genre har i princip funnits lika länge som litteraturen själv. All form av diktning har alltid givit upphov till reaktioner, som sedan ventilerats i texter av olika slag. Litteraturkritiken som vi känner den i dag - det vill säga i form av dags- och

1 Elam, Ingrid. ”Michel Houellebecq: 'Underkastelse'”. Ystads Allehanda. 2015-10-16. http:// www.ystadsallehanda.se (2015-11-08). 
kvällstidningsrecensionen - är emellertid en betydligt nyare företeelse. Denna växte fram i takt med dagspressens genombrott under det sena artonhundratalet, och definieras av Tomas Forser på följande vis: "En text om en annan text inskriven i massmediernas dramaturgiska krav och järnhårda lönelag. Stark eller svag är en sådan text alltid villkorad både av genrehistoriens formspråk och av journalistikens nu” (Forser 2002: 20). Sedan dess har den uppvisat ett antal olika tendenser över åren. Den första stora kursändringen kom på 50-talet, när recensenter inspirerade av den anglosaxiska nykritiken introducerade en delvis helt ny typ av litteraturkritik, vars fokus i mycket hög grad låg på textinterna relationer. Denna nya typ av litteraturkritik blev emellertid ganska snabbt ovidkommande. Vänstervridningen av det offentliga samtalet under 60- och 70-talet medförde i stället en mer socialrealistiskt inriktad kritik. Den politiskt medvetna kritiken kom dock att försvagas under 80-talet och framgent i takt med att en av postmodernistisk teori inspirerad litteraturkritik, med allt vad den innebar av ifrågasättande och dekonstruktion, slog igenom på tidningarnas kultursidor. De senaste tjugo, trettio åren har ett förändrat medielandskap i kombination med nyhistorisk, postkolonial och genusanalytisk teoribildning bidragit till en delvis ny slags litteraturkritik (Forser 2002: 77).

Intressant i sammanhanget är även det utrymme litteraturrecensionen ges i dags- och kvällstidningarna. Detta är långt ifrån konstant, utan har varierat tämligen kraftigt över tid. Forser skriver i Kritik av Kritiken att huvudartikeln i Göteborgs-Postens (GP) kulturdel på 60-talet ofta hade ett omfång av ungefär 9000 tecken (Forser 2002: 73). Tjugo år senare, på 80-talet, är den genomsnittliga bokrecensionen ungefär hälften så lång. Vid millennieskiftet har tidningsrecensionernas storlek reducerats ytterligare. Forser skriver att normalstorleken år 2000 ”är runt 4000 tecken i DN rakt över genrerna, något mindre i GP”(Forser 2002: 83). Genomsnittlig längd på de femton recensioner som ligger till grund för föreliggande artikel är 3900 tecken. Den trend av allt kortare recensioner som Forser skönjt under slutet av det föregående seklet tycks alltså ha avstannat (eller i varje fall ha avtagit) de senaste femton åren. Om det aktuella underlaget kan vidare noteras att det uppvisar relativt kraftiga variationer i fråga om omfång. ${ }^{2}$

Ämnet för artikeln - den moderna svenska litteraturkritiken - är mycket stort och har följaktligen genererat en mängd litteraturvetenskapliga texter. En synnerligen uttömmande översikt över den svenska litteraturkritiken sedan 1880 erbjuds i Per Rydéns bok Domedagar: Svenska litteraturkritik efter 1880 (1987). I tjugosju kapitel analyserar Rydén såväl litteraturkritiken i sig - det vill säga på ett retoriskt plan - som de publicistiska och institutionella villkor som omgärdar den. Innehållsligt ryms allt från grundliga analyser av enskilda recensioner till redogörelser för viktiga strömningar och tendenser i svensk litteraturkritiks historia.

Ett annat centralt verk i ämnet är Tomas Forsers Kritik av Kritiken (2002), vars studieobjekt är det svenska 1900-talets litteraturkritik. Precis som i Domedagar granskas en rad olika aspekter av kritiken. I ett kapitel redogör Forser för några av de teoretiska perspektiv som anlagts för att analysera den kritiska texten. I ett annat diskuteras kri-

2 Recensionerna ligger i spannet 1300 till 7300 tecken. 
tikens värderingssystem. Majoriteten av utrymmet är emellertid ägnat åt ett slags litteratursociologisk och pressteoretisk utredning av den svenska litteraturkritikens historia. Kritiken betraktas ur detta perspektiv i först hand som ett sociologiskt fenomen, det vill säga som en institution bland flera i en samhällelig kontext.

Dessa bägge verk ger en historisk överblick av den svenska litteraturkritiken sedan drygt hundra år tillbaka i tiden. Därtill finns ett flertal verk, som fokuserar enbart på en viss typ av recensioner. 1940-talets litteraturkritik analyseras grundligt i Mats Janssons Kritisk Tidsspegel (1998), vilken dessutom rymmer en intertextuell recensionsanalys. I avhandlingen Svenska recensenter läser finska böcker (1999) av Eva Herner studeras svenska recensioner av finska texter ur ett receptionsteoretiskt perspektiv. Även Herner tar upp recensionens intertextuella dimension, dock utan att anknyta till samma teoretiska tradition som Jansson. Ett tredje exempel är Rolf Yrlids avhandling Litteraturrecensionens anatomi (1972), i vilken den samlade Lagerkvist-receptionen analyseras utifrån frågor om form och värdekriterier.

\section{Syfte}

Litteraturkritiken kan precis som litteraturen studeras ur flera olika perspektiv. I artikeln Kritiken som konstnär - konstnären som kritiker i Tidskrift för litteraturvetenskap skriver Tomas Olsson att studiet av litteraturkritiken lite grovt kan delas in i två skilda problemfält: det institutionella och det retoriska. Medan det institutionella problemfältet i första hand rymmer sociologiska spörsmål, till exempel frågor kring professionalisering och kritikens publicistiska villkor, handlar det retoriska om litteraturkritiken som genre (Olsson 1998: 121). I föreliggande artikel analyseras samtliga dags- och kvällstidningsrecensioner av Michel Houellebecqs roman Underkastelse (2015) ur ett intertextuellt perspektiv. Det är den kritiska diskursen i sig (närmare bestämt dennas intertextuella dimension) som här är av intresse och studien kan därför sägas befinna sig inom det retoriska problemfältet, för att tala med Olsson.

Den kritiska texten är per definition intertextuell - i dubbel mening. För det första är den alltid en text om en annan text, det vill säga en form av metatext. För det andra, vilket Per Rydén påpekar i boken Domedagar: Svensk litteraturkritik efter 1880, är inplaceringen av den recenserande texten bland tidigare producerade texter en del av det kritiska uppdraget: "Det ingår som en av de ofrånkomliga uppgifterna i det kritiska uppdraget att placera in en text bland de tidigare producerade. Det är truistiskt att konstatera att den uppgiften fullföljs. Det viktigaste måste vara att se hur det går till” (Rydén 1987: 342). Och det är just det - det vill säga att ta reda på hur inplacerandet går till - som är målet med artikeln. Mina anspråk sträcker sig emellertid något längre än så, eftersom det intertextualitetsbegrepp som begagnas i analysen har en vidare innebörd än den gängse definitionen av termen. Artikeln syftar följaktligen inte enbart till att studera intertexternas kontextualiserande funktion, utan även till att frilägga och analysera alla former av intertextuella relationer i den kritiska texten. Centrala frågeställningar är såldes: 
1. På vilket sätt använder sig kritikerna av intertextuella referenser i recensionerna?

2. Vilken funktion har dessa?

3. Vilka former av intertextuella relationer kan identifieras i recensionsmaterialet?

För att anpassa det innehållsliga omfånget till en rimlig nivå har intertexter introducerade av Houellebecq själv (vilka har kommenterats i varierande grad av recensenterna) lämnats utanför analysen.

\section{Teori och metod}

Två texter tjänar som teoretisk grund för studien: Gérard Genettes "Strukturalisme og litteraturkritik” och Michael Riffaterres "Litteraturkritikkens diskurs”. Gemensamt för dessa två teoretiker är att de har sina rötter i den strukturalistiska skolan och att de båda i sina arbeten intresserat sig för litteraturkritiken, eller mer precist den litteraturkritiska diskursen. Genette baserar i texten "Strukturalisme og litteraturkritik" sina teorier på den strukturalistiske antropologen Claude Lévi-Strauss tankar om att en del sociala och kulturella fenomen kan liknas vid ett hobbyarbete. ${ }^{3}$ Genette parafraserar Lévi-Strauss, som i The Savage Mind skriver att hobbyarbetet "udøver sin aktivitet med instrumenter, der ikke, som f.eks. ingeniørens, er blevet skabt med henblik på denne aktivitet" (Genette 1970: 94) och vidare att dess regel alltid är att "arrangere sig med de til rådighed stående midler, og at indsætte de rester, der er fjernet fra de gamle strukturer, i nye strukturer” (Genette 1970: 94). Genette lånar alltså dessa grundläggande teorier och applicerar dem på kritiken, eftersom det enligt honom är möjligt att betrakta denna som ett slags hobbyarbete. Just litteraturkritiken sticker emellertid ut, i det att den - till skillnad från musik- och konstkritiken - begagnar sig av samma slags material som det objekt den ägnar sig åt: ”litteraturkritikken taler det samme sprog som dens objekt: den er meta-sprog, sprog om et sprog” (Genette 1970: 95). Genette lyfter även fram den strukturalistiska föreställningen om att det inte finns något litterärt objekt, utan endast en litterär funktion, som växelvis kan inrymma och exkludera vilket skriftligt objekt som helst. Det som i stället skiljer litteraturkritiken ifrån andra litterära genrer är dess avledda karaktär, det vill säga dess speciella relation till objekttexten. Detta medför en kvantitativ underlägsenhet: ”Adskillelsen mellem kritiker og forfatter består [...] i det kritiske materiales (litteraturen) sekundære og begrænsede karakter i modsætning til poesiens eller romanens materiales ubegrænsede og primære karakter (universet)” (Genette 1970: 96). Genette menar emellertid att litteraturkritiken skiljer sig från romanen och poesin även på ett mer abstrakt plan: ”Hvis forfatteren udspørger universet, udspørger kritikeren litteraturen, dvs. et univers af tegn" (Genette 1970: 97).

Genettes "Strukturalisme og litteraturkritik” ger förvisso en god inblick i den strukturalistiska litteraturteorins syn på kritiken och dess relation till övriga litterära genrer, men den säger inget konkret om intertextualitetens betydelse och funktion i den litte-

3 Lévi-Strauss introducerar i sammanhanget begreppet "bricolage”, med vilket avses något som framställts med till buds stående material. Genette lånar sedan denna term i syfte att beskriva den litteraturkritiska diskursen. 
raturkritiska diskursen. Det gör emellertid Michael Riffaterre i artikeln "Litteraturkritikkens diskurs" och därför är det de teorier som presenteras i den som i första hand ligger till teoretisk grund för artikeln. I och med att Riffaterre precis som Genette företräder en strukturalistiskt orienterad litteraturteori tangerar hans text Genettes på flera punkter. Av utrymmesskäl har därför vissa passager av ”Litteraturkritikkens diskurs” lämnats därhän i följande redogörelse. Riffaterre inleder sin artikel med att deklarera att det är "kritik forstået som en speciel form for retorik og som metadiskurs” (Riffaterre 1994: 97) som är dess studieobjekt. Detta perspektiv medför att termen objekttext introduceras, med vilken den recenserade texten avses. Riffaterre hävdar vidare att den litteraturkritiska diskursen syftar till att frilägga objekttextens komplexitet. Detta genom att den säger samma sak som texten den skriver om, fast på ett betydligt mer komprimerat och mindre sofistikerat vis: "som vi ved, er man som læser overhovedet ikke i stand til at identificere blot en enkelt trope eller figur, eller vurdere dens betydning, uden at man for det første er mere eller mindre bevidst om, at der findes en anden, enklere og mere forsimplet måde at sige det samme på” (1994: 98).

Hans grundläggande tes är att man när man som kritiker skriver om litteratur ”approprierer og udvikler [...] de former, man således kommenterer. Sprogbrugen i kritikken kan være en anden, men som hovedregel gælder en semantiske lighed” (Riffaterre 1994: 97) och att "teksten [objekttexten, min anm.] determinerer i bogstavelig forstand det metasprog, der studerer den” (Riffaterre 1994: 98). Han menar att den kritiska diskursen tenderar att annektera metaforiken i den text den behandlar för att därigenom förlänas giltighet. Eftersom det i objekttexten alltid finns luckor innebär det kritiska uppdraget emellertid alltid extrapolering, det vill säga en form av vidareskrivning av objekttexten: ”og det er just dette, der ikke bliver sagt, som den kritiske procedure vil genskabe gennem en ekstrapolation fra den tekst” (Riffaterre 1994: 105). För att övertyga läsaren om att vidareskrivningen är riktig har kritikern ett viktigt verktyg, nämligen intertextualiteten, vilken enligt Riffaterre fungerar i tre faser: "i undertrykkelsen af en del af en for fortælling eller et billede; i driften efter at genfinde en bortkommen del; og i det perspektiv man opretter for at finde denne del" (Riffaterre 1994: 107). Intertextualiteten kan till exempel anta formen av ett slags "typologi over en eksemplarisk beretning eller over dramatiske situationer. Gennem sådanne samlinger af berømte teksteksempler (topoi) og exempla overfører den literære traditions autoritet til kritikerens læsning af en ny variant af typen - topos eller exemplum i den objekttekst der er genstand for analysen” (Riffaterre 1994: 108). En annan typ av intertextualitet representeras i citatet, vilket enligt Riffaterre förmedlar "autoritet til de begivenheder, tanker eller følelser, som de omtaler, en autoritet der nu intertekstuelt videregives til de fysiske eller mentale begivenheder, teksten beretter om” (Riffaterre 1994: 109).

Metoden i artikeln baseras i hög grad på det tillvägagångsätt Mats Jansson begagnar sig av sin analys av Karl Vennbergs recension av Werner Aspenströms diktsamling Skriket och tystnaden i Kritisk tidsspegel. Recensionsmaterialet utgörs av samtliga svenska dags- och kvällstidningsrecensioner av Michel Houellebecqs roman Underkastelse, 
vilka totalt sett är femton stycken. Ett urval av de intertexter och övriga intertextuella relationer som kan registreras i dessa femton texter redovisas och diskuteras i analysavsnittet, vilket är indelat utifrån de kategorier som Janson introducerar i samband med sin analys av Vennbergs recension. Dessa kategorier kommer att presenteras mer utförligt i samband med att de aktualiseras.

\section{Analys}

Trots att detta $\mathrm{i}$ all väsentlighet är en retorisk studie, finns anledning att inledningsvis redovisa några av de kontextuella omständigheter som omger det aktuella recensionsmaterialet. Till exempel att ett par av recensionerna har publicerats i fler än en tidning (Ingrid Elams recension, för att ta ett exempel, publicerades inte enbart i Ystads Allehanda, utan även i Borås Tidning, Smålandsposten och Oskarshamns-Tidningen/Barometern), och att en av de femton recensenterna (Kristoffer Leandoer i Svenska Dagbladet) dessutom varit ansvarig för den svenska översättningen av romanen. ${ }^{4}$

De i recensionsmaterialet registrerade intertexterna har i det följande indelats i två huvudkategorier: illustrativa intertexter och dolda intertexter. Dessa sönderfaller emellertid av naturliga skäl i ett antal underkategorier, för vilka redogörs under respektive underrubrik nedan.

\section{Illustrativa intertexter}

Med termen illustrativa intertexter åsyftas all form av explicit hänvisning till annan text. Denna typ av intertextualitet kan emellertid ha olika funktion och status i den kritiska diskursen, och har därför - efter Janssons modell - indelats i två underkategorier: historiskt-genetiska intertexter samt rent illustrativa intertexter. Jansson definierar dessa på följande vis: ”I det förra fallet innebär den intertextuella relation som upprättas i kritikertexten att objekttexten i något avseende har påverkats av den anförda texten, medan den senare relationen inte hävdar något reellt inflytande, utan enbart fyller en rent illustrativ funktion” (Jansson 1998: 84). Av de femton tidningsrecensioner som ligger till grund för utredningen saknar fyra stycken helt illustrativa intertexter.

Endast tre intertexter som är att klassificera som historiskt-genetiska har registrerats $i$ de femton aktuella recensionerna. Två av dessa finnes i Leandoers anmälan i SvD. I en inskjuten bisats skriver han att den politiske expert som figurerar i romanen "uppenbart [är] modellerad efter Prousts monsieur Norpois". ${ }^{5}$ Valet av verb indikerar att Leandoer här inte talar om någon indirekt influens. Han tycks snarare mena att det är fråga om ett medvetet val av Houellebecq, att denne skapat sin politiske expert med monsieur Norpois i tankarna. Att Houellebecq är bekant med Prousts romansvit är givet (han har själv skrivit om den i bland annat genombrottsromanen Elementarpartiklarna).

4 Denna senare omständighet är värd att nämna eftersom att det inte är helt ovanligt att just översättningen kommenteras i recensioner av icke-svensk litteratur. Leandoers recension avser dock romanen på originalspråk - inte den egna översättningen.

5 Leandoer, Kristoffer. "Houellebecq om Frankrikes muslimske president”. Svenska Dagbladet. 2015-01-12. (2015-11-08). 
Den andra intertexten i Leandoers recension rör romanens stil. Han skriver om en formulering ur romanen att den "ekar svagt av Lovecraft”. ${ }^{6}$ Att Leandoer associerar till just H.P. Lovecraft är ingen slump, eftersom Houellebecq debuterade litterärt med en bok om just denne amerikanske skräckförfattare. Detta verk, som på svenska fått titeln H.P. Lovecraft. Emot världen, emot livet (1991), fungerar dessutom som en viktig intertext i Leandoers recension, vilket jag kommer att återvända till längre fram i artikeln. Till skillnad från i fallet med Proust är det här emellertid inte tal om något uppenbart inflytande, utan endast om ett "svagt" eko.

En tredje historiskt-genetisk intertext finner vi i Rasmus Landströms recension i Arbetarbladet (ArB). Landström skriver att "föreställningen om ett Europa som tas över av ett expanderande islam [...] är hämtad från den rasistiska Eurabialitteraturen” och vidare att det inte är möjligt att "tänka bort dess [Eurabialitteraturen, min anm.] inflytande på hans bok”.7 Som exempel på detta nämner han att bokens sista del inleds med ett citat av Ayatollah Khomeini: ”Om islam inte är politisk, är den ingenting alls”. ${ }^{8}$ Detta citat ligger, enligt Landström, helt i linje med Eurabialitteraturens föreställningar om islams storpolitiska ambitioner. Upprättandet av denna intertextuella relation får till följd att romanen tolkas (och kanske även värderas?) ur ett visst perspektiv.

För att svara på frågan huruvida det i det aktuella recensionsmaterialet förekommer ovanligt få historiskt-genetiska intertexter skulle krävas en studie som innefattade betydligt fler recensioner. Den enda tidigare studie som finns att jämföra med är Mats Janssons exempelanalys i Kritisk Tidsspegel men den rymmer som sagt endast en recension. Att två av de tre intertexterna av detta slag som trots allt förekommer återfinns i en recension torde i vilket fall kunna betraktas som anmärkningsvärt. Kanske ligger förklaringen i att Leandoer i och med sin roll som översättare fick en djupare inblick i Houellebecqs författarskap och därför blev mer hågad att hävda kausala samband.

Som tidigare nämnts rymmer elva av de femton recensionerna minst en illustrativ intertext. Av dessa elva refererar åtta stycken till en eller fler av Houellebecqs tidigare texter. Varje enskild text ur hans bibliografi (om man bortser från noveller och andra kortare texter) omnämns minst en gång i det analyserade recensionsmaterialet. Romanen Plattform (2001) är den text flest recensenter refererar till. ${ }^{9}$ I detta avsnitt kommer jag inledningsvis koncentrera mig på referenser och hänvisningar till texter av Houellebecq, för att sedan gå vidare och analysera övriga intertexter.

H.P. Lovecraft. Emot världen. Emot livet, Houellebecqs första bok, fungerar som jag tidigare varit inne på som en viktig intertext i Leandoers anmälan i SvD. Debutboken var enligt Leandoer "Houellebecqs sätt att introducera sig själv och sin livssyn”. ${ }^{10}$ Den var ett manifest, en programförklaring, och det är i ljuset av de tankar som presenteras i den han läser Underkastelse. Det handlar något förenklat om att litteraturens uppgift är

6 Leandoer. "Houellebecq om Frankrikes muslimske president".

7 Ibid.

8 Ibid.

9 Ingrid Elam i Ystads Allehanda, Crister Enander i Helsingborgs Dagblad, Rasmus Landström i Arbetarbladet, Jenny Högström i Dagens Nyheter samt Tua Korsström i Hufvudstadsbladet.

10 Leandoer. "Houellebecq om Frankrikes muslimske president". 
att "erbjuda ett alternativ till livet i alla dess former". ${ }^{11}$ Sett ur det perspektivet är Houellebecqs romaner iscensatta alternativ, oavsett om det gäller sexturism, kloning - eller som i det här fallet - total underkastelse. Som vi ska se längre fram är det en tolkning Leandoer inte är ensam om.

Medan Houellebecqs debutroman - Konkurrens till döds (1994) - endast nämns en gång och i förbigående, refereras det i recensionsmaterialet desto flitigare till Elementarpartiklarna (1998), hans andra roman i ordningen. I en längre anmälan i Hufvudstadsbladet skriver Tua Korsström att det bakom raseriet döljer sig "en romantiker och en känsloskildrare”. ${ }^{12}$ Den misogyne mannens förälskelse i en av honom föraktad medelålders kvinna är enligt Korsström ett återkommande tema i Houellebecqs romaner. Denna kärlek slutar emellertid alltid olyckligt: ”Den mogna generösa kvinnan dör, massakreras eller bara försvinner i likhet med den svekfulla modersfiguren i 'Elementarpartiklarna'”. ${ }^{13}$ Denna vidareskrivning - extrapolering - av objekttexten, förlänas auktoritet genom den intertextuella relation som här upprättas.

Ett betydligt mer uttalat tema i romanen är islam. Det är ett tema som Houellebecq skrivit om tidigare, bland annat i romanen Plattform. Det är därför inte överraskande att det är just den texten som flest recensenter väljer att referera till. I Arbetarbladet skriver Rasmus Lindström att det inte är "första gången Houellebecq skriver om hoten från islamismen. Redan i romanen 'Plattform' (2001) fick Michel [...] sitt kontor söndersprängt av radikaliserade muslimer”. ${ }^{14}$ Även i Ingrid Elams recension i Ystads Allehanda tas de islamkritiska tendenserna i Plattform upp. Elam hävdar emellertid att dessa tendenser inte alls är lika centrala i Underkastelse: "Hur islamofob han än kan ha framstått i sin tidigare roman 'Plattform', är han i 'Underkastelse' inte ute efter islam i första hand”. ${ }^{15}$ Jenny Högström är inne på samma linje i sin anmälan i Dagens Nyheter (DN). Högström skriver att Underkastelse visserligen är en roman helt i Houellebecqs stil, men att en sak definitivt är annorlunda: "där exempelvis Michel i Plattform var regelrätt islamofob, är protagonisten Francois i 'Soumission' [... betydligt mindre rabiat". ${ }^{16}$ Dessa tre exempel illustrerar hur en och samma intertext kan användas i flera syften. Medan Landström refererar till Plattform i syfte att placera in den recenserade romanen i en tradition av islamkritiska texter, är avsikten hos Elam och Högström den motsatta, det vill säga att lyfta fram det komplexa och tvetydiga i den aktuella romanen.

Jenny Högström refererar dessutom till Refug (2005), Houellebecqs fjärde roman. I det fallet är det emellertid inte fråga om någon tematisk parallell, utan om en värderande jämförelse. Högström skriver att Houellebecq i Underkastelse ”fångar upp ett samtidstrauma och drar det till sin spets på ett mycket mer övertygande sätt än i exempelvis

\footnotetext{
11 Ibid.

12 Korsström, Tua. ”När Frankrike blev muslimskt”. Hufvudstadsbladet. 2015-10-29. http://hbl.fi (2015-11-08).

13 Ibid.

14 Landström. ”Ny bok: Extremt provocerande - om ett Frankrike med sharialagar".

15 Elam. "Michel Houellebecq: 'Underkastelse'”.

16 Högström, Jenny. ”Michel Houellebecq: ’Soulmission'”. Dagens Nyheter. 2015-01-12. http://www.dn.se (2015-11-08).
} 
'Refug'”. Crister Enander jämför även han i sin recension i Helsingborgs Dagblad (HD) den aktuella romanen med Houellebecqs tidigare produktion. Den slutsats han drar är dock en helt annan:

Jämför man "Underkastelse” med någon av Houellebecqs tidigare böcker, till exempel "Elementarpartiklar” [sic] och "Plattform”, så framstår den som skriven av en författare som mer eller mindre tröttnat på att spela sin trista roll som aggressiv gycklare. Han framstår mest av allt som uppgiven och uttråkad. ${ }^{17}$

Intertexterna i dessa två fall är inte intressanta i sig, utan fungerar här endast som exempel på tidigare texter av Houellebecq. Det är med Houellebecqs samlade litterära produktion Underkastelse jämförs.

Ett liknande helhetsgrepp på författarskapet, fast i ett annat syfte, tas av flera recensenter. I YA skriver Ingrid Elam att "scenariot är som det brukar vara hos Houellebecq: Den verklighet han skildrar är bara ett kort steg bortom den vi kan känna igen, lite överdriven bara, som det blir när en tendens dras ut till sin yttersta konsekvens”. ${ }^{18}$ Sydsvenskans recensent Thomas Steinfeld ser i Houellebecqs författarskap en tradition av utopier och exemplifierar med Elementarpartiklarna och Kartan och Landskapet. ${ }^{19}$ Ett tredje exempel är Tua Korsströms recension i $H B$, vilken rymmer ett slags sammanfattning av Houellebecqs fyra senaste romaner. Syftet med sammanfattningen är att illustrera riktigheten i recensentens tes, som är att "Houellebecqs stora tema är västerlandets kris och i dess fotspår den västerländska mannens och kvinnans oförmåga att mötas”. ${ }^{20}$ Här är det inte objekttexten som extrapoleras, utan hela författarskapet.

Som vi sett ovan finns det i recensionsmaterialet relativt gott om referenser och hänvisningar till tidigare texter av Houellebecq. Per Rydén skriver i Domedagar, apropå den svenska Kerstin Ekman-receptionen under sjuttiotalet, att författare som fått sitt stora genombrott (vilket man med fog kan hävda att Houellebecq har) i högre grad än andra kritiseras och värderas utifrån interna jämförelser. ${ }^{21}$ Denna Rydéns tes tycks vara giltig i fallet med den svenska receptionen av Underkastelse. Det innebär emellertid inte att det i de aktuella recensionerna saknas externa jämförelser och referenser till texter skrivna av andra diktare. Som vi ska se i det följande ryms i recensionsmaterialet hänvisningar till texter från en rad olika nationer och tidsperioder.

Bland dessa finns en intertext som fler än en recensent refererar till. Det rör sig i de fallen om den nya och något diffusa genren Eurabialitteratur. Som vi sett i ett tidigare avsnitt hävdar Rasmus Landström i sin anmälan i $A r B$ att denna litterära subgenre utövat ett visst inflytande på Houellebecqs roman. Ifrågavarande intertext fyller emellertid ytterligare en funktion i Landströms text: den fungerar som ett slags utgångspunkt för hela

17 Enander, Christer. ”Narren som har tappat bjällrorna”. Helsingborgs Dagblad. 2015-10-16.

http://www.hd.se (2015-11-08).

18 Elam. ”Michel Houellebecq: 'Underkastelse'”.

19 Steinfeld, Thomas. "I islamska republiken Frankrike”. Sydsvenskan. 2015-01-09.

http://www.sydsvenskan.se (2015-11-08).

20 Korsström. "När Frankrike blev muslimskt”.

21 Rydén. Domedagar: Svensk litteraturkritik efter 1880, s. 419. 
recensionen. Han inleder nämligen sin anmälan med att redogöra för den diskussion i den litterära offentligheten som omgärdade utgivningen av boken:

När Michael Houellebecqs roman ”Underkastelse” kom på franska förra året [sic] höll världen andan. Houellebecqs roman, sades det, skildrade ett samtida Frankrike där Muslimska broderskapet hade kommit till makten, där kvinnorna hade lämnat arbetsmarknaden och sharialagar införts. [...] Kritikerna kunde dock pusta ut. "Underkastelse" var ingen rasistisk hatskrift utan en välskriven dystopi. Inom den franska kritikerkåren var det ingen som beskrev boken som en islamofobisk skrift och ingen kallade den "Eurabialitteratur" (som flera befarade att den var). ${ }^{22}$

Denna kontextualiserande inledning föranleder frågan ”Men kom Houellebecq lite väl lätt undan? Det frågar jag mig när boken nu finns att läsa på svenska", ${ }^{23}$ kring vilken fortsättningen av recensionen kretsar. Bland annat drar Landström en indirekt parallell mellan Underkastelse och Anders Behring Breiviks manifest 2083 - A European Declaration of Independence när han skriver att det var just det scenario som Houellebecq målar upp sin roman som Breivik utgick ifrån i sin hatskrift. Han är dock tydlig med att påpeka att det i övrigt inte föreligger något ideologiskt släktskap texterna emellan. Svaret på den inledande frågan tycks bli: nej, Houellebecq kom inte för lätt undan. Utan att vara lika central har samma intertext en i princip identisk funktion i Anders Sjögrens recension i Västerbottens-Kuriren. Precis som sin kritikerkollega på Arbetarbladet hänvisar Sjögren till Eurabialitteraturen i syfte att illustrera de spekulationer som florerade veckorna innan romanen gavs ut: "Upplagt för den riktiga stjärnsmällen som skulle få provokatörer som Lars Vilks att framstå som branschens småhandlare; nu skulle en etablerad författare bidra till den så kallade Eurabien-litteraturen [...] Nu ... blev det inte så.”24

Romanens huvudperson, den desillusionerade litteraturprofessorn François, frammanar associationer till andra litterära figurer hos två av de femton recensenterna. Nils Forsberg beskriver honom i sin recension i Expressen som "en ofräsch släkting till Mersault i Albert Camus 'Främlingen'”. ${ }^{25}$ Forsberg tillägger dock att François, till skillnad från Mersault, aldrig skulle komma sig för att skjuta någon, just eftersom han är en i raden av Houellebecqs livströtta och halvt apatiska romanfigurer. Dala-Demokratens recensent Tony Samuelsson liknar i stället Houellebecqs protagonist vid huvudpersonen i J.M. Coetzees Onåd: ”Han är inte helt olik JM Coetzees litteraturprofessor i Onåd, en roman om huvudpersonens själviska utnyttjande av unga kvinnor. Coetzee tvingar dock sin professor att vakna upp i samtiden och ta ansvar för sina handlingar. En sådan tydlig sensmoral skulle aldrig falla Houellebecq in”. ${ }^{26}$ Precis som Forsberg är han noga med

22 Landström. ”Ny bok: Extremt provocerande - om ett Frankrike med sharialagar”.

23 Ibid.

24 Sjögren, Anders. ”Osannolikt trovärdigt”. Västerbottens-Kuriren. 2015-10-18. http://www.vk.se (2015-11-08).

25 Forsberg, Nils. ”Ett liv på knä hos Michel Houellebecq”. Expressen. 2015-01-12. http://www.expressen.se (2015-11-08).

26 Samuelsson, Tony. ”Allt och alla är utbytbara”. Dala-Demokraten. 2015-10-30. http://www.dalademokraten.se (2015-11-08). 
att poängtera att liknelsen endast är partiellt giltig. Däri ligger det gemensamma i dessa två exempel. Både Samuelsson och Forsberg tycks vilja framhäva det typiskt houellebecqska i François person genom att peka på den diskrepans deras jämförelser trots allt rymmer.

Som sades inledningsvis varierar antalet intertextuella hänvisningar i recensionsmaterialet ganska kraftigt. Flitigast i att referera till andra texter är Tua Korsström, vars recension i Hufvudstadsbladets allt som allt inrymmer ett tiotal illustrativa intertexter. Av dessa har de som avser Houellebecqs tidigare texter diskuterats tidigare i detta avsnitt. Av de övriga lyfts två titlar - George Orwells 1984 och Aldous Huxleys Brave New World - fram i samband med en redogörelse för hur romanen mottogs i hemlandet.27 De har alltså introducerats i ett tidigare skede av den intertextuella process som ifrågavarande recension är del av. Dessa två jämförelser förblir emellertid i princip okommenterade i Korsströms text. En av titlarna upprepas dock i alluderad form i recensionen, vilket avhandlas i artikelns nästkommande avsnitt. Desto mer intressant är i stället referensen till Jonathan Swift och dennes A Modest Proposal: "Man vet aldrig var man har Houellebecq. I sin skoningslösa människo- och samhällsanalys tar han till samma drastiska medel som biskop Jonathan Swift i dennes ryktbara 'Ett anspråkslöst förslag'. Swifts grymma ironi fick hans belackare att kasta sig över honom i stället för de företeelser han gisslade. Detsamma har gång på gång hänt Houellebecq”. ${ }^{28}$ Jämförelsen ovan är intressant eftersom recensenten med den vill mena att det finns beröringspunkter mellan Swift och Houellebecq i två avseenden. För det första i det mod och i den totala respektlöshet inför den goda tonen som de båda uppvisar i respektive text. För det andra i den oförståelse de bägge mötts av.

De två sista intertextuella referenserna som här ska avhandlas rör beskrivningen av islam i romanen. Följande passus är hämtad ur Thomas Steinfelds recension i Sydsvenskan:

Den behöver inte vara den dummaste av alla religioner, så som Michel Houellebecq själv en gång påstod, men den behöver inte heller vara den klokaste och vänligaste [...] Den islamska religionen, så som Michel Houellebecq framställer den i ”Underkastelse”, är en udda blandning av "Tusen och en natt” och den turkiske predikanten Fethullah Gülens läror - och eftersom den är så uppenbarligen påhittad duger den knappast som motbild till västvärldens självvållade undergång. ${ }^{29}$

Till att börja med kan fastslås att "Fethullah Gülens läror” är en i sammanhanget ovanligt smal referens (definitivt den smalaste i det aktuella recensionsmaterialet), och man kan fråga sig hur många av Sydsvenskans läsare som känner till Fethullah Gülen och dennes religiösa läror. Hänvisningen till sagosamlingen Tusen och en natt tycks i sammanhanget tjäna syftet att peka på just det sagoartade och orealistiska i Houellebecqs skildring av islam. Mer subtilt skulle även en kritik mot vad recensenten anser vara en alltför mytologiserad och förenklad världsbild kunna läsas in i denna senare referens.

27 Korsström. "När Frankrike blev muslimskt".

28 Ibid.

29 Steinfeld. "I islamska republiken Frankrike”. 
För denna tolkning finns emellertid inget explicit stöd i texten. Steinfeld är i vilket fall som helst tydlig i sin dom. Denna dom gäller emellertid endast romanens framställning av islam och han är inte sen med att påpeka att Underkastelse samtidigt har sina förtjänster (dock inte utan reservationer): "Över långa sträckor är romanen rolig att läsa, men nöjet gäller de udda idéerna, de sneda vinklarna och den fullständiga respektlösheten gentemot alla slags 'värden'. Nöjet gäller inte polemiken.”30

Sammanfattningsvis kan konstateras att rent illustrativa intertexter förekommer i majoriteten av de studerade recensionerna. Skälen till varför man väljer att referera till andra texter har emellertid visat sig vara högst varierande. Bland annat används denna form av intertextualitet i jämförande (som i Nils Forsbergs liknelse av François vid Mersault i Albert Camus Främlingen), kategoriserande (som i Ingrid Elams redogörelse för Houellebecqs samlade texter), kontextualiserande (som i Rasmus Landströms hänvisning till Eurabialitteraturen och den livliga debatt som omgav utgivningen av romanen), beskrivande (som i Kristoffer Leandoers referens till H.P. Lovecraft) och värderande (som i Thomas Steinfelds parallell till sagosamlingen Tusen och en natt avseende Houellebecqs framställning av islam) syften. I slutskedet av analysen aktualiserades en intressant fråga som det tidigare inte funnits anledning att ta upp, nämligen den om vilka förkunskaper recensionsläsaren kan förväntas ha. Det är emellertid ett i första hand sociologiskt spörsmål och har därför lämnats därhän.

\section{Dolda intertexter}

Med termen dolda intertexter avses här all slags implicit intertextualitet. Det kan röra sig om den typ av imitation som Riffaterre menar karakteriserar den kritiska diskursen, men i kategorin ryms även anspelningar, allusioner och textimmanenta relationer, det vill säga den kritiska texten i sig. ${ }^{31}$ Just eftersom dessa intertexter är dolda kan ingen garanti för att samtliga har identifierats ges. Men i och med att artikelns avsikt inte är att registrera varenda intertext i det relativt omfattande recensionsmaterialet, utan endast analysera ett urval av dessa, borde detta inte kunna anses vara något problematiskt. I det följande kommer först ett par allusioner/anspelningar och sedan en rad exempel på hur den kritiska texten lånar form- och stildrag ur objekttexten att avhandlas.

När Ingrid Elam i sin recension i Ystads Allehanda skriver att "de territorier Houellebecq ritar kartor över är inte huvudsaken”32 vet den som kan sin Houellebecq att det är en allusion på hans roman Kartan och landskapet (2010). Elams stilistiska grepp skulle mycket väl även kunna förklaras utifrån Riffaterres teori om att kritikertexten tenderar att låna och vidareutveckla det bildspråk den studerar i objekttexten. Intressant är här att den aktuella metaforen inte här hämtad ur objekttexten utan ur en av Houellebecqs tidigare texter. Principen är dock densamma. En liknande allusion fast på en annan text finner vi i Tua Korsströms recension i Hufvudstadsbladet: "Houellebecq ersatte helt sonika sina dekadenta individer med klonade varelser i ny skön värld och fortsatte att

30 Ibid.

31 Jansson. Kritisk tidsspegel, s. 84.

32 Elam. "Michel Houellebecq: 'Underkastelse'”. 
klona mänskligheten i romanen Refug”. ${ }^{33}$ Du sköna nya värld är den svenska titeln på Aldous Huxleys roman Brave New World, vilken som vi tidigare sett förekommer som en illustrativ intertext i recensionen. Att just denna text alluderas får därmed sin förklaring. Att det över huvud taget refereras till Brave New World i samband med kritiken av Underkastelse kan givetvis förklaras genom att peka på det gemensamma i den dystopiska tematiken. Jag tror emellertid att det finns en annan minst lika giltig förklaring, nämligen att Huxleys roman fungerar som en viktig intertext i Elementarpartiklarna. Det vill säga att den intertextuella hänvisningen är betingad - och i och med det auktoriserad - av en intertextuell relation i en av Houellebecqs tidigare texter.

Per Rydén tangerar såväl Genettes som Riffaterres teorier när han i Domedagar skriver att "lyrikrecensenten arbetar likaväl som sina kritikerkollegor med texter och däribland även med sådana textelement, som är lånade eller åtminstone påverkade av den diktare han uppehåller sig vid”. ${ }^{34}$ Mats Jansson är inne på samma spår i Kritisk Tidsspegel i vilken han fastslår att: "litteraturkritiken kan [...] beskrivas som en fundamentalt parasitär diskurs”. ${ }^{35}$ Han tillägger emellertid att den kan begagna sig av material även från andra källor än den aktuella objekttexten, till exempel från en annan recension eller tidningsartikel. I sin recension i Dala-Demokraten från den 30 oktober 2015 beskriver Tony Samuelsson François liv som "inplastat”. Detta ordval blir intressant mot bakgrund av att det ett par veckor tidigare (16 oktober) i Dagens Nyheter publicerades en artikel av Aris Fioritos med titeln "Konsten att beskriva livet som inplastad migrän”. Huruvida detta är ett slumpmässigt sammanträffande eller ej är visserligen omöjligt att svara på. Klart är i alla fall att adjektivet inplastad är en relativt ovanlig metafor och att det av den anledningen är anmärkningsvärt att den under en kort tidsperiod förekommer i två skilda texter på samma ämne.

Två exempel på hur kritikertexten tenderar att imitera objekttexten - på flera plan - får avrunda analysen. Det första är taget ur Andreas Sjögrens recension i VästerbottensKuriren: "Houellebecq är på sitt allra bästa berättarhumör, blandar högt och lågt, trilskande mikrovågsugnar och avlopp med klosterinteriörer och islams fem pelare och, förstås, huvudets högflygande [sic] teoribildningar med underlivets jordnära bestyr" ${ }^{36}$ Det intressanta med citatet ovan är att Sjögren själv iscensätter det han kommenterar, det vill säga att blanda det höga med det låga. Detta sker därtill både på ett semantiskt och syntaktiskt plan. Följande stycke ur Jenny Högströms recension är påfallande likt Sjögrens passus ovan: "Och när det partikulära korsar det generella med ofelbar tajming, som när en historisk händelse som presidentsvalsdebatten 2022 störs av en tjutande mikrovågsugn, då är Houellebecq faktiskt i sitt esse” ${ }^{37}$ Här är förvisso den trilskande mikrovågsugnen utbytt mot en tjutande dito, men dessa två exempel illustrerar med all önskvärd tydlighet riktigheten i Riffaterres tes om att den som skriver om litteratur "ap-

33 Korsström. ”När Frankrike blev muslimskt”.

34 Rydén., Domedagar: Svensk litteraturkritik efter 1880, s. 342.

35 Jansson. Kritisk tidsspegel, s. 94.

36 Sjögren. "Osannolikt trovärdigt".

37 Högström. ”Michel Houellebecq: 'Soulmission’”. 
proprierer og udvikler [...] de former, man således kommenterer. Sprogbrugen i kritikken kan være en anden, men som hovedregel gælder en semantiske lighed” (Riffaterre 1994: 97).

\section{Sammanfattning}

Målet med artikeln har varit att svara på de frågeställningar som formulerades inledningsvis. Gällande vilken funktion de intertextuella referenserna har i den kritiska texten är svaret att det är högst varierande. Den historiskt-genetiska intertexten har som namnet anger en i första hand förklarande funktion, det vill säga att hävda något slags kausalitet. Därtill kommer de rent illustrativa intertexterna, vilka har visat sig kunna användas i en rad olika syften: för att jämföra, för att beskriva, för att värdera, för att kategorisera samt för att kontextualisera. Sammantaget har alltså sex huvudsakliga användningsområden kunnat urskiljas.

Gällande artikelns tredje frågeställning kan konstateras att det recensionsmaterialet i allra högsta grad gör att finna stöd för de intertextuella relationer som enligt Riffaterre karakteriserar den litteraturkritiska diskursen.

\section{Källförteckning}

\section{Recensionsmaterialet}

Bergqvist, Martin (2015), "Medlöperiet och maktens korruption”. Norrbottens-Kuriren. 2015-10-30. http://www.kuriren.nu (2015-11-08).

Ekenberg, Kristian (2015), "Gapskrattframkallande satir”. Dalarnas Tidningar. 2015-10-16. http://www.dt.se (2015-11-08).

Elam, Ingrid (2015), ’Michel Houellebecq: 'Underkastelse’”. Ystads Allehanda. 2015-10-16. http://www.ystadsallehanda.se (2015-11-08).

Enander, Christer (2015), ”Narren som har tappat bjällrorna”. Helsingborgs Dagblad. 2015-10-16. http://www.hd.se (2015-11-08).

Eriksson, Maria (2015), ’Trovärdigheten känns bortglömd”. Norran. 2015-11-03. http://norran.se (2015-11-08).

Forsberg, Nils (2015), ’Ett liv på knä hos Michel Houellebecq”. Expressen. 2015-01-12. http://www.expressen.se (2015-11-08).

Frändén, Johanna (2015), ’Islam tar makten”. Aftonbladet. 2015-01-16. http://www.aftonbladet.se (2015-11-08).

Högström, Jenny (2015), ’Michel Houellebecq: 'Soulmission’”. Dagens Nyheter. 2015-01-12. http://www.dn.se (2015-11-08).

Korsström, Tua (2015), ”När Frankrike blev muslimskt”. Hufvudstadsbladet. 2015-10-29. http://hbl.fi (2015-11-08).

Landström, Rasmus (2015), ”Ny bok: Extremt provocerande - om ett Frankrike med sharialagar". Arbetarbladet. 2015-10-16. http://www.arbetarbladet.se (2015-11-08).

Leandoer, Kristoffer (2015), "Houellebecq om Frankrikes muslimske president”. Svenska Dagbladet. 2015-01-12. (2015-11-08). 
Samuelsson, Tony (2015), ”Allt och alla är utbytbara”. Dala-Demokraten. 2015-10-30. http://www.dalademokraten.se (2015-11-08).

Sjögren, Anders (2015), ”Osannolikt trovärdigt”. Västerbottens-Kuriren. 2015-10-18. http://www.vk.se (2015-11-08).

Steinfeld, Thomas (2015), ”I islamska republiken Frankrike”. Sydsvenskan. 2015-01-09. http://www.sydsvenskan.se (2015-11-08).

Wilhelmsson, Johan (2015), "Västerlandet går under med gott humör”. Norrköpings Tidningar. 2015-10-22. http://www.nt.se (2015-11-08).

Övriga källor

Fioritos, Aris (2015), ”Konsten att beskriva livet som inplastad migrän”. Dagens Nyheter. 2015-10-16. http://www.dn.se (2016-01-05).

Forser, Tomas (2002), Kritik av Kritiken. Gråbo: Bokförlaget Anthropos AB.

Genette, Gérard (1970), ”Strukturalisme og litteraturkritik”. I Madsen, Peter (red.). Strukturalisme: En Antologi. Köpenhamn: Rhodos.

Herner, Eva (1999), Svenska recensenter läser finska böcker: En studie i receptionen av finsk prosa, översatt på 1960-talet. Uppsala.

Houellebecq, Michel (2015), Underkastelse. Stockholm: Albert Bonniers Förlag.

Jansson, Mats (1998), Kritisk tidsspegel. Stockholm: Brutus Östlings Bokförlag Symposion $\mathrm{AB}$.

Olsson, Tomas (1998), Kritiken som konstnär - konstnären som kritiker. Tidskrift för litteraturvetenskap no. 3-4: 121-132.

Riffaterre, Michael (1994), ”Litteraturkritikkens diskurs”. Ny Poetik no. 3: 97-110.

Rydén, Per (1987), Domedagar: Svensk litteraturkritik efter 1880. Lund.

Yrlid, Rolf (1972), Litteraturrecensionens Anatomi. Lund: CWK Gleerup Bokförlag. 